\title{
Efficacy of Pre-Planting Herbicides on Meloidogyne Incognita Infecting Okra Plant under Greenhouse Conditions
}

\author{
Sergany M. I1, S. B. Gad.2
}

\author{
${ }^{1}$ Pesticides Dept. Fac. Of Agric., Mansoura Univ. Dk. Egypt \\ ${ }^{2}$ Nematology Res. Unit, Agric. Zool. Dept, Fac. Of Agric., Mansoura Univ. Dk. Egypt
}

\begin{abstract}
A pot experiment was carried out in order to evaluate the efficacy of four pre-planting herbicides i.e. Amex 48\%, Atrazine, Nitrofen and Stomp 5\% in comparison with Oxamyl on Meloidogyne incognita infecting okra plant cv Hyper Doki 1 under greenhouse conditions $\left(25 \pm 5^{\circ} \mathrm{C}\right)$. It was evident that all tested pesticides improved plant growth parameters and reduced nematode with various grades. Atrazien overwhelmed other treatments in improving plant growth parameters for plant length (19.84\%), whole plant fresh weight $(29.32 \%)$ and shoot dry weight $(66.03 \%)$, respectively, followed by Nitrofen for the same plant criteria with values of $15.53,21.67$ and $59.86 \%$, respectively. Moreover, Oxamyl as a nematicide showed extensive values in improving plant growth criteria and ranked first in suppressing nematode population density in soil, galls and eggmass numbers. Atrazine accomplished the reasonable reduction percentage in nematode population density in soil followed by that of Amex $48 \%$ application with value of $25.27 \%$. There was no significant differences between the values of RGI and EI indices which achieved equal values with those of nematode alone(4).
\end{abstract}

Keywords: herbicides, amex, atrazine, nitrofen, stomp, nematode, okra, Meloidogyne

\section{INTRODUCTION}

Herbicides are chemicals that used to control injurious weeds all over the world. The most common application of herbicides occurs in row-crop farming, where they are applied before or during planting to maximize crop production by minimizing other harmful flora. A few hebicides have been reported to have an effect on population of plantparasitic nematodes. herbicide mixture of acifluorfen and bentazon decreased populations of Heterodera glycines (Browdie et al., 1994). In some cases, nematode populations have increased following application of herbicides. The herbicide vernolate, metributzin and trihralin increased the number of soybean cyst nematode (H. glycines) egg production by 37 and 134 percent in soybean (Kraus, et al., 1982). The mixture of herbicide alachlor and nematicide fenamiphos caused a late season reappearance of $H$. glycines population (Sipes and Shmitt. 1989). Indifferent responses of nematodes to herbicides treatment have also been reported by Liphadzi et al., (2005). Few information are reported on the effect of the common herbicides on nematode in Egypt. The present investigation was conducted to determine the efficacy of some commonly used pre- planting herbicides i.e. Amex 48\%, Atrazine, Nitrofen and Stomp 5\% on root-knot nematodes, Meloidogyne incognita infecting okra plant Hyper Doki 1 under greenhouse conditions.

\begin{abstract}
MATERIALS AND METHODS
A pot experiment was carried-out at the Nematology Research Unit (NRU)of the Agricultural Zoology Department, Fac. of Agric., Mansoura University in order to determine the effect of four pre-planting herbicides i.e. Amex 48\%, Atrazine, Nitrofen and Stomp 5\% in comparison with Oxamyl (Vydate $24 \%$ E.C) at the recommended dose $(0.3 \mathrm{ml})$ on Meloidogyne incognita reproduction and the resulting effect on okra plant growth (Table 1). Twenty plastic pots $(15 \mathrm{~cm}$-diam) containing $1600 \mathrm{~g}$.steam-sterilized clay sand soil $(1: 1, \mathrm{v}: \mathrm{v})$ treated with four herbicides each and mixed with soil. After seven days, thirty five pots were sown with three seeds of okra each. Two weeks later, okra seedlings were thinned to one seedling / pot and inoculated with 1000 M. incognita second stage juvenile to thirty seedlings and left five seedlings (pots) without nematode and any treatments to serve as control.
\end{abstract}

This article is published under the terms of the Creative Commons Attribution License 4.0 Author(s) retain the copyright of this article. Publication rights with Alkhaer Publications. Published at: http://www.ijsciences.com/pub/issue/2015-09/

DOI: 10.18483/ijSci.769; Online ISSN: 2305-3925; Print ISSN: 2410-4477 
Each treatment was replicated five times. Treatments were as followed:

1.N+ Amex 48\%

2- $\mathrm{N}+$ Atrazine

3- N+ Nitrofen,

4- N+ Stomp 5\%

$5-\mathrm{N}+$ Oxamyl $(0.3 \mathrm{ml} / \mathrm{pot})$,

$6-\mathrm{N}+$ alone, and

7-Check (plant free of nematode and any treatment).

Plastic pots were then arranged in randomized complete block design in the greenhouse and treated horticulturally and irrigated with water as needed. Plants were harvested after 45 days from nematode inoculation and plant growth criteria i.e. shoot and root lengths and fresh wight as well as shoot dry weights were determined and recorded. Infected roots of each plant /treatment were washed with tap water, fixed in $4 \%$ formalin for $24 \mathrm{~h}$ and examined for the number of galls and eggmasses per root system, and recorded. The root gall index (RGI) and egg mass index (EI) were estimated according to the scale given by Taylor and Sasser (1978) as follows: $0=$ no galling or egg-masses, 1=1-2 galls or egg-masses, $2=$ 3-10 galls or egg-masses, $3=11-30$ galls or eggmasses, $4=31-100$ galls or egg-masses and $5=$ more than 100 galls or egg-masses. M. incognita $\left(\mathrm{J}_{2} \mathrm{~S}\right)$ were separately extracted from $250 \mathrm{cc}$ soil of each treatment by sieving and modified Baermann technique (Goodey, 1957), counted and recorded. This process was repeated three times and the average of $\mathrm{J} 2 / 250 \mathrm{cc}$ soil was determined and recorded.

Statistically, the obtained data were subjected to analysis of variance (ANOVA) (Gomez and Gomez, 1984) followed by Duncan's multiple ranges to compare means (Duncan, 1955).

Table (1) : Chemical composition of tested herbicides.

\begin{tabular}{|c|c|c|c|}
\hline $\begin{array}{l}\text { Common } \\
\text { name }\end{array}$ & Scientific name & Chemical composition & $\begin{array}{l}\text { Chemical } \\
\text { formula }\end{array}$ \\
\hline $\begin{array}{c}\text { Amex } 48 \% \\
\text { E.C }\end{array}$ & $\begin{array}{c}\text { 4-(1,1-dimethylethyl)- } N \text { - } \\
\text { (1-methylpropyl)-2,6- } \\
\text { dinitrobenzenamine }\end{array}$ & $\left(\mathrm{CH}_{3}\right)_{3} \mathrm{C}-$ & $\mathrm{C} 14 \mathrm{H} 21 \mathrm{~N} 3 \mathrm{O} 4$ \\
\hline $\begin{array}{c}\text { Atrazine } \\
\text { W.P }\end{array}$ & $\begin{array}{c}\text { 6-chloro-4-N-ethyl-2-N- } \\
\text { propan-2-yl-1,3,5- } \\
\text { triazine-2,4-diamine }\end{array}$ & & C8H14CIN5 \\
\hline $\begin{array}{c}\text { Nitrofen } \\
\text { W.G }\end{array}$ & $\begin{array}{c}\text { 2,4-Dichloro-1-(4- } \\
\text { nitrophenoxy)benzene }\end{array}$ & & $\mathrm{C} 12 \mathrm{H} 7 \mathrm{Cl} 2 \mathrm{NO} 3$ \\
\hline $\begin{array}{c}\text { Stomp 5\% } \\
\text { E.C }\end{array}$ & $\begin{array}{c}N \text {-(1-ethylpropyl)-3,4- } \\
\text { dimethyl-2,6- } \\
\text { dinitrobenzenamine }\end{array}$ & $\mathrm{CH}_{3}-$ & C13H19N3O4 \\
\hline Oxamyl & $\begin{array}{c}\text { 2-(dimethylamino })-N- \\
{[(\text { methylcarbamoyl }) \text { oxy }]-} \\
\text { 2-xoethanimidothioate }\end{array}$ & & $\mathrm{C}_{7} \mathrm{H}_{13} \mathrm{~N}_{3} \mathrm{O}_{3} \mathrm{~S}$ \\
\hline
\end{tabular}




\section{RESULTS AND DISCUSSION}

Data in Tables (2\&3) documented the impact of using four pre-planting herbicides i.e. Amex $48 \%$, Atrazine, Nitrofen and Stomp 5\% in comparison with Oxamyl (Vydate $24 \%$ E.C) at the recommended dose $(0.3 \mathrm{ml} / \mathrm{pot})$ on development and reproduction of Meloidogyne incognita infecting okra plant cv Hyper Doki 1 under greenhouse conditions. Obviously results indicated that all tested pesticides improved plant growth parameters and reduced nematode with various degrees as compared to nematode alone. Among tested herbicides, Atrazien overwhelmed other treatments in improving plant growth characters i.e. total plant length (19.84\%), fresh weight of the whole plant $(29.32 \%)$ and shoot dry weight $(66.03 \%)$, respectively, followed by Nitrofen for the same plant criteria with values of $15.53,21.67$ and $59.86 \%$, respectively. However, Stomp $50 \%$ gave the intermediate values in this respect, which were amounted to $13.04,18.41$ and
$39.19 \%$ for total plant length, fresh weight of whole plant and shoot dry weight as well, respectively. Likewise, similar results was noticed in the case of Amex $48 \%$ treatment with slight percentage increases in total plant fresh weight $(8.50 \%)$, shoot dry weight (7.49\%), and shoot dry weight (13.54), respectively. Moreover, Oxamyl as a nematicide showed considerable values in improving plant growth criteria even though it was higher than tested herbicides which averaged 26.98, 33.86 and $67.93 \%$ for the same plant characters, respectively, comparing to nematode alone (Table 2). Correspondingly, plant receiving none of the tested herbicides and free of nematode showed considerable values of percentage increase of plant growth characters that were amounted to $28.80,48.45$ and $70.78 \%$ for plant length, total plant fresh weight and shoot dry weight comparing to nematode alone, respectively (Table 2).

Table (2): Impact of four pre-planting herbicides in comparison with oxamyl on growth response of okra cv. Hyper Doki 1 infected by Meloidogyne incognita under greenhouse conditions $\left(25 \pm 5^{\circ} \mathrm{C}\right)$.

\begin{tabular}{|c|c|c|c|c|c|c|c|c|c|c|}
\hline \multirow{3}{*}{ } & \multicolumn{10}{|c|}{ *Plant growth response } \\
\hline & \multicolumn{2}{|c|}{ Length (cm) } & \multirow{2}{*}{$\begin{array}{c}\text { Total } \\
\text { Length }\end{array}$} & \multirow{2}{*}{$\begin{array}{c}* * \text { Inc } \\
\%\end{array}$} & \multicolumn{2}{|c|}{ Fresh weight (g) } & \multirow{2}{*}{ 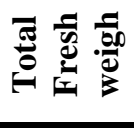 } & \multirow{2}{*}{$\begin{array}{c}* * \text { Inc } \\
\%\end{array}$} & \multirow{2}{*}{$\begin{array}{c}\text { Shoot dry } \\
\text { weight }\end{array}$} & \multirow{2}{*}{$\underset{\%}{* * \text { Inc }}$} \\
\hline & Shoot & Root & & & Shoot & Root & & & & \\
\hline Amex 48\% & $\begin{array}{l}67.5 \\
a b c\end{array}$ & $\begin{array}{c}28.2 \\
\mathrm{ab}\end{array}$ & $\begin{array}{c}95.7 \\
\text { bc }\end{array}$ & 8.50 & $\begin{array}{c}109.9 \\
\text { bc }\end{array}$ & $\begin{array}{c}25.0 \\
\text { bc }\end{array}$ & $\begin{array}{c}134.9 \\
\mathrm{~cd}\end{array}$ & 7.49 & $\begin{array}{c}47.8 \\
\mathrm{~cd}\end{array}$ & 13.54 \\
\hline Atrazine & $\begin{array}{l}80 \\
a b\end{array}$ & $25.7 \mathrm{~b}$ & $\begin{array}{c}105.7 \\
\mathrm{ab}\end{array}$ & 19.84 & $\begin{array}{c}129.0 \\
\mathrm{ab}\end{array}$ & $\begin{array}{c}33.2 \\
\text { bc }\end{array}$ & $\begin{array}{c}162.3 \\
\text { abc }\end{array}$ & 29.32 & $\begin{array}{c}69.9 \\
\mathrm{a}\end{array}$ & 66.03 \\
\hline Nitrofen & $\begin{array}{c}70.92 \\
\text { abc }\end{array}$ & $31.0 \mathrm{ab}$ & $\begin{array}{c}101.9 \\
\text { abc }\end{array}$ & 15.53 & $\begin{array}{c}115.4 \\
\mathrm{abc}\end{array}$ & $\begin{array}{c}37.2 \\
\mathrm{~b}\end{array}$ & $\begin{array}{c}152.7 \\
\text { bcd }\end{array}$ & 21.67 & $\begin{array}{c}67.3 \\
\mathrm{ab}\end{array}$ & 59.86 \\
\hline Stomp 5\% & $\begin{array}{c}66.5 \\
\text { bc }\end{array}$ & $33.2 \mathrm{a}$ & $\begin{array}{r}99.7 \\
\text { abc }\end{array}$ & 13.04 & $\begin{array}{c}115.9 \\
a b c\end{array}$ & $\begin{array}{c}20.7 \\
\mathrm{c}\end{array}$ & $\begin{array}{c}148.6 \\
\text { bcd }\end{array}$ & 18.41 & $\begin{array}{c}58.6 \\
\text { bc }\end{array}$ & 39.19 \\
\hline Oxamyl & $\begin{array}{c}80.8 \\
\mathrm{a}\end{array}$ & $32.7 \mathrm{ab}$ & $\begin{array}{c}112.0 \\
\mathrm{a}\end{array}$ & 26.98 & $\begin{array}{c}132.8 \\
\mathrm{a}\end{array}$ & $\begin{array}{c}35.1 \\
b\end{array}$ & $\begin{array}{c}168.0 \\
a b\end{array}$ & 33.86 & $\begin{array}{c}70.7 \\
\mathrm{a}\end{array}$ & 67.93 \\
\hline $\mathbf{N}$ alone & $\begin{array}{c}61.2 \\
\mathrm{c}\end{array}$ & $27 \mathrm{ab}$ & $\begin{array}{c}88.2 \\
\mathrm{c}\end{array}$ & ------ & $\begin{array}{c}104.7 \\
\mathrm{c}\end{array}$ & $\begin{array}{c}20.7 \\
\mathrm{c}\end{array}$ & $\begin{array}{c}125.5 \\
\mathrm{~d}\end{array}$ & ---- & $\begin{array}{c}42.1 \\
d\end{array}$ & ---- \\
\hline Check & $\begin{array}{c}81.0 \\
\text { a }\end{array}$ & $31 \mathrm{ab}$ & $\begin{array}{c}113.6 \\
\text { a }\end{array}$ & 28.80 & $\begin{array}{c}132.7 \\
\mathrm{a}\end{array}$ & $\begin{array}{c}53.6 \\
\text { A }\end{array}$ & $\begin{array}{c}186.3 \\
\mathrm{a}\end{array}$ & 48.45 & $\begin{array}{c}71.9 \\
\text { A }\end{array}$ & 70.78 \\
\hline LSD & 14.0 & 7.3 & 16.8 & ---- & 21.6 & 13.9 & 27.5 & --------- & 11.2 & - \\
\hline
\end{tabular}

$\mathrm{N}=1000 \mathrm{~J} 2$ of $M$. incognita

*Each value is a mean of five replicates. Means in each column followed by the same letter(s) did not differ at $\mathrm{p}<0.05$ according to Duncan multiple-range test.

$* *$ Increase $\%=$ Treatment $-\mathrm{N}$ alone (Untreated) $\quad \times 100$

$\mathrm{N}$ alone (Untreated)

Data presented in Table (3) showed nematode population densities in soil; and number of galls and egg-masses on okra plant infested with $M$. incognita as affected by four pre-planting application of herbicides i.e. Amex 48\%, Atrazine, Nitrofen and Stomp 5\% in comparison with oxamyl under greenhouse conditions. It is evident that nematode criteria were also influenced by tested herbicides with some extent comparing to nematode alone.

The application of Atrazine as pre planting herbicide accomplished the reasonable reduction percentage in 
nematode population density in soil that averaged $26.93 \%$, followed by that of Amex $48 \%$ application with value of $25.27 \%$. The relative lowest reduction percentage of this nematode criterion was resulted by treatment of Nitrofen with value of $18.32 \%$ as compared with nematode alone, (Table 3).

Regarding, galls and egg-mass numbers, a low reduction in number of galls and eggmasess on okra roots was recorded by all tested herbicides with values of 7.34 and $36.94 \%$ for Atrazine, respectively. In the meantime, it was evident that Amex 48\%, showed the lowest gall and eggmass reduction percentages with values 2.96 and $26.71 \%$ for the same criteria, respectively.

Concerning root galling and eggmasses indices, there was no significant differences between the values of RGI and EI indices which achieved equal values with those of nematode alone (4).

Moreover, Oxamyl as a systemic nematicide ranked first in suppressing nematode population density in soil, galls and eggmass numbers on roots with values of $68.66,90.91$ and $100.0 \%$, respectively, with low RGI and EI indices which averaged 1.3 and zero vs 4 for nematode alone.

Table (3): Influence of pre-planting herbicides in comparison with oxamyl on Meloidogyne incognita infecting okra cv. Hyper Doki 1 under greenhouse conditions $\left(25 \pm 5^{\circ} \mathrm{C}\right)$.

\begin{tabular}{|c|c|c|c|c|c|c|c|c|}
\hline Treatments & $\begin{array}{c}\text { Number of } \\
\text { nematodes } \\
\text { in soil }\end{array}$ & $\begin{array}{l}0 \\
0 \\
0 \\
0\end{array}$ & 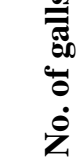 & 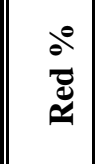 & $\vec{\underbrace{}}$ & 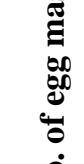 & 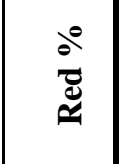 & 牙 \\
\hline Amex 48\% & $\begin{array}{c}3522.3 \\
\text { bc }\end{array}$ & 25.27 & $\begin{array}{c}88.6 \\
\text { a }\end{array}$ & 2.96 & 4.0 & $\begin{array}{c}62.3 \\
b\end{array}$ & 26.71 & 4.0 \\
\hline Atrazine & $\begin{array}{c}3444.3 \\
\text { c } \\
\end{array}$ & 26.93 & $\begin{array}{c}84.6 \\
\text { a } \\
\end{array}$ & 7.34 & 4.0 & $\begin{array}{c}53.6 \\
\text { c }\end{array}$ & 36.94 & 4.0 \\
\hline Nitrofen & $\begin{array}{c}3850.3 \\
\text { b }\end{array}$ & 18.32 & $\begin{array}{c}86.3 \\
\text { a }\end{array}$ & 5.48 & 4.0 & $\begin{array}{c}56.0 \\
\text { c }\end{array}$ & 34.12 & 4.0 \\
\hline Stomp 5\% & $\begin{array}{c}3550.3 \\
\text { bc }\end{array}$ & 24.68 & $\begin{array}{c}86.3 \\
\mathbf{a}\end{array}$ & 5.48 & 4.0 & $\begin{array}{c}58.0 \\
\text { bc }\end{array}$ & 31.76 & 4.0 \\
\hline Oxamyl & $\begin{array}{c}1477.3 \\
\text { d }\end{array}$ & 68.66 & $\begin{array}{c}8.3 \\
\text { b }\end{array}$ & 90.91 & 1.3 & $\begin{array}{l}\mathbf{0} \\
\mathbf{d}\end{array}$ & 100.00 & $\mathbf{0}$ \\
\hline Nematode alone & $\begin{array}{c}4713.6 \\
\mathrm{a} \\
\end{array}$ & $-\cdots$ & $\begin{array}{c}91.3 \\
\mathbf{a} \\
\end{array}$ & $-\cdots$ & 4.0 & $\begin{array}{c}85.0 \\
\text { a } \\
\end{array}$ & ----- & 4.0 \\
\hline LSD & 397.8 & ---- & 13.3 & ------ & & 6.2 & -------- & \\
\hline
\end{tabular}

$\mathrm{N}=\mathrm{ck}=1000 \mathrm{~J} 2$ of $M$. incognita

*Each figure represents the mean of five replicates.

* Means in each column followed by the same letter did not differ at $\mathrm{P}<0.05$ according to Duncan's multiple range tests.

*The root gall index (RGI) and egg mass index (EI) were estimated according to the scale given by Taylor and Sasser (1978) as follows: $0=$ no galling or egg-masses, $1=1-2$ galls or egg-masses, $2=3-10$ galls or egg-masses, $3=11-30$ galls or egg-masses, $4=31-100$ galls or egg-masses and 5= more than 100 galls or egg-masses.

\footnotetext{
** $\mathrm{RF}=$ Rate of build-up $=$ Reproduction Factor $=$ Final population $(\mathrm{Pf})$ Initial population $(\mathrm{Pi})$
}

Apparently, the importance of utilizing herbicides are essential for controlling harmful weeds within nontarget effect in soil micro-organisms such as 
phytonematodes in various agricultural crops. However, results of the present work proved this phenomenon in influencing $M$. incognita development associated with ameliorating plant growth parameters of infected okra cv. Hyper Doki 1 under the application of four pre-planting herbicides i.e. Amex $48 \%$, Atrazine, Nitrofen and Stomp 5\% in comparison with Oxamyl under greenhouse conditions. These findings are in accordance with that of Browdie et al., (1994) who reported that herbicide combination of acifluorfen and bentazon decreased populations of Heterodera glycines. Similar trend observed by Singh and Nandram (2004) who found that use of herbicides in rice and wheat had a significant harmful effect on nematode populations. On the other hand, The observed data were disagreed with Kraus et al., (1982) who found that herbicide vernolate, metributzin and trihralin increased the number of soybean cyst nematode $(H$. glycines) egg production by 37 and 134 percent in soybean. The response of different soil nematode groups to herbicide application may indicate a change in soil ecosystem processes. The change in nematode community structure may alter the soil decomposition pathway (Zhao et al. 2013). The toxic effect of tested herbicides may be due to chemical composition of their integrated materials. To improve the accepting of the effects of herbicides on the soil nematode population, additional large-scale, longterm and comparable research experiments with different agroecosystems are required to be done.

\section{REFERENCES}

1) Browdie, I.A., G.L. Tylka, L.P. Pedigo and M.D.K. Own (1994). Response of Heterodera glycines population to a post emergence herbicide mixture and stimulated insect defoliation. J. Nematol. 26:498- 504.

2) Byrd, D.W.; T. Kirkpatrick and K. Barker (1983). An improved technique for clearing and staining plant tissues for detection nematodes. J. Nematol., 15 (3): 142-143.

3) Duncan, D.B. (1955). Multiple range and multiple, F-test. Biometrics, 11: 1-42.

4) Gomez, K. A. and A.A. Gomez (1984). Statistical procedures for Agricultural Research. 2nd Ed., John Wiley \&Sons: Inc., New York.

5) Goodey, J.B. (1957). Laboratory methods for work with plant and soil nematodes. Tech. Bull. No. 2. Min. Agric. Fish Ed. London, 47 pp.

6) Kraus, R.G.; R. Noel and D.L. Edwards (1982). Effect of preemergence herbicide and aldicarb on Heterodera glycines population dynamics and yield of soybean (Abstr.) J. Nematol. 14 (14).

7) Liphadzi, K.B.; K. Al-Khati; C.N. Bensch; P.W. Stalhlman; J.A. Dile; J.T.R. Todd; C.W. Rice; K.J. Horak and G. Head (2005). Soil microbial and nematode communities as affected by glyphosate resistant cropping system. Weed Sci. 53: 536545 .

8) Singh, A.P. and O. Nandram. 2004. Long term effects of fertilizer and herbicides on a nematode population under a rice-wheat-cowpea system. Pest Science and Management. 29(2): 20-27.

9) Sipes, S.B. and D.P. Shmitt (1989). Development of Heterodera glycines as affected by alachlor and feneamiphods. J. Nematol. 21(1):24-33.

10) Taylor, A. L., and J. N. Sasser (1978). Biology, identification and control of root-knot nematodes (Meloidogyne species). Raleigh, NC: North Carolina State University Graphics.

11) Zhao, J. ; A. D. Neher ; S. Fu; Z. Li and K. Wang (2013).Nontarget effects of herbicides on soil nematode assemblages. Pest Manag Sci; 69: 679-6 